\title{
The rediscovery of the Cebu Flowerpecker Dicaeum quadricolor, with notes on other forest birds on Cebu, Philippines
}

GUY C. L. DUTSON, PERLA M. MAGSALAY and ROB J. TIMMINS

\begin{abstract}
Summary
The Cebu Flowerpecker Dicaeum quadricolor, considered extinct since 1906, was rediscovered in a very small $\left(<2 \mathrm{~km}^{2}\right)$ patch of largely degraded forest near Tabunan, Cebu island, Philippines, in 1992. This patch also holds at least four of the five other bird forms endemic to Cebu that are known to be extant. There appears to be no other forest with any closed canopy elsewhere on the island, and the Tabunan site, although within the Central Cebu National Park, could disappear within five years (through clearance for firewood by local villagers) without immediate intervention.
\end{abstract}

\section{Introduction}

Cebu is a relatively large island, totalling $5,088 \mathrm{~km}^{2}$, in the central Philippines. Despite its close proximity to other large islands such as Negros and Bohol, its avifauna is sufficiently distinct for it to have been considered a biogeographical region in its own right (McGregor 1920). It has two endemic species of bird (Cebu Flowerpecker Dicaeum quadricolor and Black Shama Copsychus cebuensis) and 12 endemic subspecies (Dickinson et al. 1991). ICBP (1992) listed Cebu as one of nine "endemic bird areas" in the Philippines, and it is inferred from this to be of high importance for biodiversity in other groups.

Cebu has suffered from deforestation more than any other large island in the Philippines: in 1986 it had no closed dipterocarp forest, an estimated $15 \mathrm{~km}^{2}$ of open dipterocarp forest (i.e. a mere $0.3 \%$ of the island's land area), and $4 \mathrm{~km}^{2}$ of mangrove (SSC 1988). The island's relatively flat profile (its highest point is approximately $920 \mathrm{~m}$ altitude) and the early development of Cebu City contributed to the destruction of the natural forests at a rate unparalleled on other islands. Even the earliest collectors remarked on how little forest remained on Cebu, with Bourns and Worcester (1894) commenting a century ago that "as the small amount of forest remaining in the island is rapidly being cleared away we fear that $D$. quadricolor will become extinct before many years". The species was still present in 1906 (McGregor 1907) but could not be found by Rabor (1959), who led collecting work on Cebu from 1947 to 1956 and who very reasonably surmised that deforestation had caused the loss of this and eight subspecies endemic to Cebu, plus most other forest species on the island. King (1978-1979) 
duly listed these forms as extinct in or around 1906, and they (mostly) appeared again in a notable table in which Dickinson et al. (1991) could list only one other global extinction from the entire country (Loriculus philippensis siquijorensis from Siquijor). Neverthless, ICBP (1992) listed Cebu as critical in the scheme of priority areas for global conservation, with a three star rating for threatened status.

The last account of birds on Cebu was by Rabor (1959), although some more recent records by P.M.M. and R. S. Kennedy were included in Dickinson et al. (1991). P.M.M. has studied birds on Cebu intermittently since 1982, notably researching the endemic Copsychus cebuensis (Magsalay 1983, 1985, 1989).

In 1992, with the advice and logistical help of the Philippine Wetland and Wildlife Conservation Foundation, Inc. (PWCF), previously the Asian Wetland Bureau-Philippines, visits were made by R.J.T. and G.C.L.D. with PWCF staff to the largest remaining forest in $\mathrm{Cebu}$, around the village of Tabunan to the west of Mt Manunggal. On 17 February 1992, R.J.T., together with PWCF researchers A. G. Toledo and D. Asane, climbed Mt Manunggal; having found no significant areas of forest, R.J.T. made his way over to the Tabunan forest, which had been noticed earlier in the day, about $3 \mathrm{~km}$ further down and on the opposite side of the valley. On 27 December 1992 G.C.L.D. and T. H. Fisher, along with the PWCF research team headed by P.M.M., spent five hours in this forest. Two brief visits were made in the intervening months by P.M.M. and her team, once with T. H. Fisher. Other areas of secondary forest and plantations occur on Cebu, and most have been visited in recent years by P.M.M. with her team.

\section{The forest patch at Tabunan}

Prior to the 1992 visits, satellite maps showing forest cover (SSC 1987) were consulted. The Cebu map shows a single area of $15 \mathrm{~km}^{2}$ of forest, situated over the Mt Manunggal massif, with the largest extent of forest on the summit, from which a strip runs off to the south. However, no forest was seen around the summit of Mt Manunggal when it was climbed from the north-west in February 1992. The forest found was west of the village of Tabunan and the main Mt Manunggal massif, in an area marked as deforested by SSC (1987). Local people confirmed that this forest was the largest remaining tract in the area, which we would estimate as far less than $15 \mathrm{~km}^{2}$. Small stands of large trees were visible elsewhere in this and adjacent valleys, but none had any mature closed-canopy forest. One of the best areas outside the Tabunan ridge, with about 3 ha of large trees devoid of undergrowth and 1 ha of secondary forest with thick undergrowth, was visited on 27 December 1992.

The main forest comprises a strip less than $4 \mathrm{~km}$ long on a sloping limestone ridge running down into the valley. It is split into two main blocks by an area of landslide in the middle, and it averages $200 \mathrm{~m}$ or less in width. At its southern end it is about $450-500 \mathrm{~m}$ in altitude, while at the northern end it is probably at around $600-650 \mathrm{~m}$. Small areas of the forest had virtually closed canopy and large trees to over $25 \mathrm{~m}$ tall. However, the total area of such forest is possibly less than 10 ha. Some parts of the forest are naturally broken because of the rugged limestone terrain, and much of the flatter areas have been cleared for 
kaingin (shifting agriculture). Several recently cut large trees, in the process of being sawn into planks, were also noted. Clearance had continued through 1992 (T. H. Fisher verbally).

Elsewhere on Cebu a number of plantations, mainly of exotic tree species, have been established. However, these areas support far fewer birds compared to scrub forest of native tree species. Only those species that are more tolerant of degraded habitat have survived: Copsychus cebuensis, for example, can be found in secondary regrowth with bamboo thicket. So far there have been no suspected records of Dicaeum quadricolor from any of these areas.

\section{Significant bird observations at Tabunan in 1992}

\section{Cebu Flowerpecker Dicaeum quadricolor}

Probable Cebu Flowerpeckers were seen twice in 1992: a pair in the late afternoon of 17 February by R.J.T. (Timmins 1992) and one individual on 24 September by P.M.M.

The pair seen by R.J.T. were immediately recognizable as a male and female related to Bicoloured Flowerpecker $D$. bicolor, a species which closely resembles D. quadricolor (at least from below) and one with which he was familiar. For some 15 minutes they moved restlessly through the crown of a fairly low tree (sometimes into adjacent trees), rarely perching for any length of time, the male seemingly in pursuit of the female. R.J.T. had witnessed similar behaviour in both Bicoloured and Red-striped Flowerpeckers D. australe, but during the period of observation at Tabunan neither bird called, which seemed surprising in view of the vocal nature of $D$. bicolor in particular. Both birds briefly vanished, then a pair of flowerpeckers flew over, again not calling, and there were no further sightings.

The bird on 24 September was only seen from below and again the views did not allow conclusive separation from Bicoloured Flowerpecker, although this latter is allospecific and has never been recorded from Cebu. However, a family group of a male, female and juvenile $D$. quadricolor was seen on 27 December. These were seen from all angles and were quite clearly this species (Dutson 1993).

The male was seen initially towards the top of a tree on the edge of primary forest on very broken boulder-strewn ground. It remained in the tree for about a minute, calling frequently but not feeding on the tree's small fruits. The call was similar to the ticking call of Red-striped Flowerpecker but the notes were lower-pitched with longer intervals between them. It frequently gave a thin "seep" similar to the begging call of a young European Robin Erithacus rubecula, sometimes alternating the two calls, a calling pattern rarely heard from other Philippine flowerpeckers (T. H. Fisher verbally 1992). Over the next 20 minutes, the male bird frequently returned to and foraged in this tree, but it was not seen to take any fruit. It was joined by a female and juvenile for about five minutes on one occasion; these other birds were sometimes audible in nearby trees. The male fed away from the female and juvenile, and twice flew close to and called insistently at one observer. The male returned briefly after 150 
minutes, after which the observers left. No other calls or possible sightings of this species were recorded.

The male was similar to a male $D$. bicolor but the underparts were a duskier grey except for a white moustachial stripe between the dark upper face and the grey throat, and a less well defined white mid-line stripe from the lower breast to the rear belly (these two stripes are either not present or not obvious on bicolor). A large crimson patch on the back - a feature absent in bicolor - extended from the back of the nape to the rump. The rump itself was not seen, being concealed by the wing tips. The rest of the upperparts were glossy black and all bare parts appeared to be black. The bill was short and stubby, appearing very similar to that of bicolor. The female bird was a dull version of the male without the red back; the upperparts were dark brown and the underparts pale greyish-brown. It appeared to be much duller than female bicolor. The juvenile bird was aged by its orange basal two-thirds of the otherwise dark bill; its upperparts were olive-brown with a grey wash to the sides of the neck and bright green fringes to the remiges, while the underparts were a dirty greyish colour.

The Cebu Flowerpecker's scientific name quadricolor refers to the fact that the male's plumage is composed of four colours, the red, black and greyish-white of the description above plus greenish-yellow on the rump. This latter was not seen in the 1992 bird, which was seen from above only with its wings closed, so this rump patch must cover a small area. The description and illustration in duPont (1971) shows the white midline stripe but not the white moustachial stripe. However, the type description (Tweeddale 1877) has the underparts a pale silvery-greyish white with chin and cheeks almost pure white. Salomonsen (1960) described the female as very similar to female bicolor but more brownish olive-green on the upperparts. McGregor (1907) collected an immature male bird which had underparts as in the adult but upperparts and tips of the tertials and greater coverts dull olive-green; this appears to be intermediate between adult and juvenile plumages. The juvenile we saw in 1992 closely matched the description of a juvenile bicolor seen by G.C.L.D. at Malpalon, Mindoro, on 29 September 1991: dull green-brown upperparts, dull olive underparts, bill with pale base to the lower mandible. The Flame-crowned Flowerpecker D. anthonyi has been considered perhaps the next closest relative of quadricolor (Salomonsen 1960), but a juvenile seen by G.C.L.D. at Mt Katanglad, Mindanao, on 5 October 1991 was quite different: warm buffy-brown above, dusky on the underparts with a paler central stripe and fine dark scaling on the throat. Scaling of the underparts has not been seen by G.C.L.D. in any other flowerpecker species in the Philippines.

Flowerpeckers appear to have an extended breeding season in the Philippines with frequent breeding records throughout the fieldwork periods of the authors (see, e.g., Evans et al. in press). Records in Dickinson et al. (1991) cover most months, but with more records in the period February to August inclusive; the one previous breeding record for quadricolor was in June (Bourns and Worcester in McGregor 1909-1910).

The Cebu Flowerpecker has always been scarce. Everett took just one of this species out of a total of 282 birds collected on Cebu (Tweeddale 1877). McGregor 
(1907) spent about six weeks collecting on Cebu and obtained five quadricolor out of a total of 50 Dicaeum flowerpeckers, calling it "rare and strictly confined to forest"; this was the last comment by an observer with experience of the species. Three other flowerpeckers have fared very poorly on the island. The Orange-bellied Flowerpecker $D$. trigonostigma, like quadricolor a bird of closedcanopy forest, has a subspecies pallidius endemic to Cebu which has not been seen since 1920 (see below). The Striped Flowerpecker D. aeruginosum and Pygmy Flowerpecker D. pygmaeum have not been recorded recently, both species occurring elsewhere at low densities and aeruginosum appearing to be restricted to mature forest (pers. obs., Brooks et al. 1992, Dutson et al. 1992); both may now be extinct on Cebu. The final flowerpecker known from the island, D. australe, remained common in 1992 in all areas of the Tabunan forest visited as well as scrub. Dickinson et al. (1991) suggested that the extinction of quadricolor may have been caused in part by aggressive competition from australe, but no interactions between these species were noted in 1992, although they were noted in close proximity on 17 February.

Judging by the stout bill and the behaviour of the birds we saw in 1992, $D$. quadricolor is likely to be a frugivorous canopy species. The similar D. bicolor is most frequently observed in fruiting trees where it is often gregarious, with up to eight seen together, and is locally fairly common; however it too is largely restricted to mature closed-canopy forest (pers. obs., Brooks et al. 1992, Dutson et al. 1992).

On 13 March 1993 four Cebu Flowerpeckers - one certainly a male (singing) and all very actively chasing each other, hovering and calling - were seen at close range and tape-recorded from a ledge overlooking the canopy at Tabunan by I. Gardner, N. Bostock and two PWCF staff; the birds appeared to have bright pink legs and looked more "bull-necked" than D. bicolor (I. Gardner in litt.).

\section{Other forest birds endemic to Cebu}

Rabor (1959) distinguished and reviewed the status of two species and eight subspecies endemic to Cebu. He recorded only one of these, Copsychus cebuensis, and judged all the others to be extinct. With recent taxonomic revisions, two species and 12 subspecies are now considered to be endemic to Cebu (Dickinson et al. 1991), the additional four subspecies being marked below with an asterisk $\left(^{*}\right)$. While it is heartening that both full species are now known to be extant, regrettably the same can be said for only four of the endemic subspecies, the probable extinctions being marked with a sword $(t)$, the possible extinction with a question mark (?).

tAmethyst Brown-dove Phapitreron amethystina frontalis was last recorded in 1892 (Rabor 1959).

?Philippine Hanging-parrot Loriculus philippensis chrysonotus was purportedly last recorded in 1929 (Rand 1959) or at least 1920 (Baud 1976), and is listed as extinct by Dickinson et al. (1992). Birds of undetermined race were recorded by Rabor (1959), in 1992 (at least two on 17 February and at least four on 27 December) and 1993 (at least two on 13 March 1993: I. Gardner in litt.). Because 
the species is commonly kept as a pet and presumed escapes have been collected outside their normal subspecific range (Rabor 1959), it cannot be assumed that these records apply to chrysonotus, but it is clearly possible that they do.

${ }^{*}$ Coppersmith Barbet Megalaima haemacephala cebuensis is extant. At least 20 birds were recorded on 27 December 1992 at Tabunan.

*+White-bellied Woodpecker Dryocopus javensis cebuensis is considered probably extinct by Dickinson et al. (1991). It would appear to be known only from the three specimens on which the recent description was based, all taken before the turn of the century (Kennedy 1987).

+Bar-bellied Cuckoo-shrike Coracina striata cebuensis was last recorded in 1906 (Rabor 1959), although P.M.M. saw what she considers likely to have been this bird at Casili, Consolacion, in March 1982.

tBlackish Cuckoo-shrike Coracina coerulescens altera was last recorded in 1906 (Rabor 1959).

tStreak-breasted Bulbul Hypsipetes siquijorensis monticola was last recorded in 1906 (Rabor 1959). The nominate subspecies occurs widely in scrub and degraded forest on Siquijor (Evans et al. 1992). The Cebu subspecies may have had different ecological requirements, since it was reported to Rabor (1959) as being restricted to mountains, or else it may have suffered competition from the Philippine Bulbul H. philippinus. The latter is still common on Cebu (about 90 were seen on 27 December 1992) but does not occur on Siquijor.

Black Shama Copsychus cebuensis survives in small numbers in scrub with second-growth forest, plantations and bamboo thickets throughout the island. Studies by Magsalay $(1983,1985,1989)$ confirmed Rabor's (1959) assertion that it had adapted to bamboo thickets and second growth. It occurs in small numbers in such habitat in the municipalities of Consolacion, Liloan, Minglanilla, Carcar, Argao, Pinamungahan, Badian and on the outskirts of the cities of Cebu, Mandaue and Toledo. At least five birds were heard in the Tabunan forest on 17 February 1992 (a "good population" was noted there on 13 March 1993: I. Gardner in litt.); and on 24 February 1993 three individuals were also found in Mantalungon, Dalaguete. It is very possible that populations still exist in areas not yet checked. An important population (50 birds in c. 1,00o ha of fragmented scrub forest and bamboo thicket) survives in P.M.M.'s study site near Casili, Consolacion and Mandaue City; but this is now greatly threatened by a nearby housing subdivision development, which has already caused the loss of land holding two families (seven individuals) of shamas.

tPhilippine Oriole Oriolus steerii assimilis was last recorded in 1906 (Rabor 1959). At this time, it was noted as "exceedingly common in the small amount of forest left on Cebu" (Bourns and Worcester in McGregor 1909-1910).

*Elegant Tit Parus elegans visayanus is extant. It was seen by Rabor's (1959) team, when it was treated as the race albescens. P.M.M. saw two birds in Buhisan in May 1981 and caught one individual during a survey of Sudlon National Park in March 1986 (the area is now mostly agricultural land). On each of our visits to Tabunan in 1992 the species was recorded: several birds were seen on 17 February (also in smaller tree stands on Mt Manunggal), one was caught on 24 September, and two were recorded on 27 December.

${ }^{*}$ White-vented Whistler Pachycephala homeyeri major was recorded in 1947-1956 under the name $P$. plateni winchelli (Rabor 1959), and was considered extant by 
Dickinson et al. (1991). However, the only record since the 1950s appears to be by P.M.M., who caught one at Casili, Consolacion, on 29 September 1990.

tOrange-bellied Flowerpecker Dicaeum trigonostigma pallidius was last recorded in 1920 (Baud 1976). At the turn of the century it was noted as the "most common species of the family Dicaeidae in Cebu" (McGregor 1907).

Everett's White-eye Zosterops everetti everetti was considered extinct by Rabor (1959), but six birds were seen in the Buhisan Reforestation Project near Cebu City in May 1985 (Dickinson et al. 1991). P.M.M. and H. Miranda saw at least five individuals in Cantipla, Cebu City, on 5 November 1989. Eight birds were recorded on 27 December 1992 at Tabunan.

Also of interest in 1992 were records of Blue-crowned Racquet-tailed Parrot Prioniturus discurus (two on 17 February, five on 24 September and three on 27 December). This species was listed as near-threatened in Collar and Andrew (1988) and was not found outside large areas of forest on Negros and Mindoro in 1991 (Brooks et al. 1992, Dutson et al. 1992). Seven Purple Needletails Hirundapus celebensis were seen on 27 December, a species previously unrecorded from Cebu (Dickinson et al. 1991).

\section{Conservation status of the forest}

The forest block at Tabunan is under extreme threat and must be considered a crucial site for biodiversity conservation especially if, as suspected, it is the only remaining original forest on Cebu. The area is so small that removal of just a few of the larger trees could have disastrous consequences; certainly, if present trends continue, the forest could easily disappear within five years. The greatest current threat is clearance for timber for local consumption and kaingin. The area comes within the boundaries of the Central Cebu National Park (documentation of which, held in the Protected Areas Data Unit of the World Conservation Monitoring Centre, indicates that its boundaries embrace 11,894 ha, and that the endemic tree Cinnamomum cebuense, once thought extinct, still survives there). However, this status affords little if any protection and in fact allows unregulated use of the area by outsiders.

The most important measure to save the forest would probably be a conservation-based education programme for the people of Tabunan. This village almost certainly controls the future of the forest, as access from other areas is much more difficult. Thus a strong education programme, including discussions on the needs of the local people, would most effectively secure the future of the forest.

Other conservation priorities could include active protection of the forest, with the possible appointment of a permanent forest warden. The expansion of the area through natural regrowth and reforestation with native species would be a further long-term goal, but should not be implemented until the remaining forest has full protection.

P.M.M. of the PWCF has already implemented schemes to protect and study the Black Shama. PWCF have a proposal of the highest priority for the protection and management of the patch of forest at Tabunan, and they are currently seeking funding for this. 


\section{Acknowledgements}

We wish to thank the people of Tabunan, the staff of PWCF and Tim Fisher for their invaluable help with access to the site and company in the field, I. Gardner for his and N. Bostock's 1993 records, and M. J. B. Green for data from the World Conservation Monitoring Centre. G.C.L.D. is extremely grateful to the financial sponsors who generously supported his visit: Bird Exploration Fund; A. J. Burton Charitable Trust; A. S. Butler Charitable Trust; D. M. Charitable Trust; Mr and Mrs Dutson; People's Trust for Endangered Species; and Selwyn College, Cambridge.

\section{References}

Baud, F. J. (1976) Oiseaux des Philippines de la collection W. Parsons. I. Cebu, Samar, Romblon, Tablas et Sibuyan. Revue Suisse Zool. 83: 497-513.

Bourns, F. S. and Worcester, D. C. (1894) Preliminary notes on the birds and mammals collected on the Menage Scientific Expedition to the Philippine Islands. Occas. Pap. Minnesota Acad. Nat. Sci. 1: 1-64.

Brooks, T. M., Evans, T. D., Dutson, G. C. L., Anderson, G. Q. A., Asane, D. C., Timmins, R. J. and Toledo, A. G. (1992) The conservation status of the birds of Negros, Philippines. Bird Conserv. Internatn. 2: 273-302.

Collar, N. J. and Andrew, P. (1988) Birds to watch: the ICBP world checklist of threatened birds. Cambridge, U.K.: International Council for Bird Preservation (Techn. Publ. 8).

Dickinson, E. C., Kennedy, R. S. and Parkes, K. C. (1991) The birds of the Philippines. London: British Ornithologists' Union (Check-list 12).

duPont, J. E. (1971) Philippine birds. Greenville, Delaware: Delaware Museum of Natural History.

Dutson, G. (1993) Rediscovery of the Cebu Flowerpecker Dicaeum quadricolor confirmed. OBC Bull. 17: 14.

Dutson, G. C. L., Evans, T. D., Brooks, T. M., Asane, D. C., Timmins, R. J. and Toledo, A. G. (1992) The conservation status of the birds of Mindoro, Philippines. Bird Conserv. Internatn. 2: 303-325.

Evans, T. D., Dutson, G. C. L. and Brooks, T. M., eds. (in press) Cambridge Philippines Rainforest Project 1991 final report. Cambridge, U.K.: BirdLife International (Study Report).

Evans, T. D., Magsalay, P., Dutson, G. C. L. and Brooks, T. M. (1992) The conservation status of the forest birds of Siquijor, Philippines. Forktail 8: 89-96.

ICBP (1992) Putting biodiversity on the map. Cambridge, U.K.: International Council for Bird Preservation.

Kennedy, R. S. (1987) New subspecies of Dryocopus javensis (Aves: Picidae) and Ficedula hyperythra (Aves: Muscicapidae) from the Philippines. Proc. Biol. Soc. Washington 100: $40-43$.

King, W. B. (1978-1979) Red data book, 2: Aves. Second edition. Morges, Switzerland: International Union for Conservation of Nature and Natural Resources.

Magsalay, P. M. (1983) Research report: the study of the Cebu Black Shama, Philippines. Pp.78-79 in Proceedings, Second East-Asian Bird Protection Conference. Taipei: Animal Protection Association of the Republic of China.

Magsalay, P. M. (1985) Research report: study of the Black Shama (Copsychus cebuensis Steere) from Cebu, Philippines. Pp.129-131 in Proceedings, Third East-Asian Bird Protection Conference, Tokyo: Wild Bird Society of Japan. 
Magsalay, P. M. (1989) Conservation of Cebu Black Shama (Copsychus cebuensis, Steere). Unpublished report to the Fourth East-Asian Bird Protection Conference.

McGregor, R. C. (1907) Notes on birds collected on Cebu. Philippine J. Sci. 2: 298-309.

McGregor, R. C. (1909-1910) A manual of Philippine birds. Manila, Philippines: Bureau of Science.

McGregor, R. C. (1920) Some features of the Philippine ornis with notes on the vegetation in relation to the avifauna. Philippine J. Sci. 16: 361-437.

Rabor, D. S. (1959) The impact of deforestation on the birds of Cebu, Philippines, with new records for that island. Auk $76: 37-43$.

Rand, A. L. (1959) Late records of the Cebu Golden-backed Hanging Parakeet. Avicult. Mag. 65: $177-178$.

Salomonsen, F. (1960) Notes on flowerpeckers (Aves, Dicaeidae) 2. The primitive species of the genus Dicaeum. Amer. Mus. Novit. 1991.

SSC [Swedish Space Corporation] (1987) Land cover maps of the Philippines at 1: 250,000 .

SSC [Swedish Space Corporation] (1988) Mapping of the natural conditions of the Philippines. Final report, 30 April 1988.

Timmins, R. (1992) Is the Cebu Flowerpecker extinct? OBC Bull. 15: 10-11.

Tweeddale (1877) Contributions to the ornithology of the Philippines. No. II. On the collection made by Mr A. H. Everett in the island of Zebu. Proc. Zool. Soc. Lond. 755769.

GUY C. L. DUTSON

1 High Way, Broadstone, Dorset BH18 9NB, U.K.

PERLA M. MAGSALAY

Philippine Wetland and Wildlife Conservation Foundation Inc., A. Sing Building, R. Duterte Street, Banawa, 6ooo Cebu City, Philippines

ROB J. TIMMINS

25 Cradley Road, Cradley Heath, Warley, West Midlands B64 6AG, U.K. 